\title{
A Graduate Seminar Series for Dual BS/MS Degree Students
}

\author{
Elizabeth A. DeBartolo and Edward Hensel \\ Mechanical Engineering Department, Rochester Institute of Technology
}

\begin{abstract}
At the Rochester Institute of Technology, undergraduate students have the unique opportunity to pursue a dual BS and MS degree in engineering. Many outstanding students take advantage of this opportunity but in order to obtain both degrees in a reasonable amount of time, work on the thesis must begin during the student's third or fourth year. While the students are technically capable of completing the early stages of their thesis work at this time, they often lack the softer skills that many educators remember learning from their graduate student peer groups when they were in school. Since RIT is a primarily undergraduate institution, where many of the MS students are just advanced undergraduates, this peer group does not exist for many of our dualdegree students who are taking four courses per quarter, holding down jobs, and participating in a variety of on-campus extracurricular activities. To facilitate this skill set development in early $\mathrm{BS} / \mathrm{MS}$ students, a graduate seminar series has been piloted this year. Topics have been selected and timed to help guide students through the process of finding a thesis topic/advisor, starting their thesis research, and developing a plan of action. The long-term goal is to use the Graduate Seminar course as a way to help entering BS/MS students to learn the soft skills needed to succeed from upperclassmen and build a support network among these students.
\end{abstract}

Background

RIT's Mechanical Engineering department has a primarily undergraduate focus, and it is a co-op institution, where ME students are required to complete five co-op blocks beginning in their third year. RIT also offers an MS or MEng degree, depending on whether or not the student wants to pursue thesis research. There are two options for pursuing a master's-level degree: the student may enter as a full- or part-time student who has already completed the bachelor's degree, or the student may apply for a dual BS/Masters program as a second-year student at RIT. The focus of this paper is the BS/MS student, who wishes to complete all the standard undergraduate requirements and graduate from RIT with a BS and MS degree at the same time.

BS/MS students have a very rigorous schedule (Table 1) that provides them with two extra quarters of coursework during their five years at RIT. This is done by waiving one of the five co-op blocks and allowing them to begin co-ops over the summer after their second year instead of during the third year. While BS/MS students are required to take two fewer courses toward their MS degrees than full-time MS-only students are, they are still required to take an extra eight courses beyond the BS to satisfy the MS requirements. This means that no additional course release is available for thesis work, if the students are to graduate with their BS-only 
peers in May of their $5^{\text {th }}$ year. In order for students to be certified for their degrees, they must successfully complete both degrees by the end of their $6^{\text {th }}$ year at RIT. This means that a failure to complete the MS degree requirements results in a failure to receive the BS degree as well.

Table 1: Typical BS/MS program outline. "BS Coursework" indicates that students are taking typical BS courses. Only the additional MS-related courses are specified.

\begin{tabular}{|c|c|c|c|c|}
\hline Year & Fall & Winter & Spring & Summer \\
\hline \hline 1 & \multicolumn{3}{|c|}{ BS Coursework } & Off \\
\hline 2 & \multicolumn{3}{|c|}{ BS Coursework } & Co-op \#1 \\
\hline 3 & Grad Math I & Co-op \#2 & BS Coursework & Co-op \#3 \\
\hline 4 & Grad Core \#1 & $\begin{array}{c}\text { Grad Core \#2 } \\
\text { Grad Math II }\end{array}$ & Grad Core \#3 & Co-op\#4 \\
\hline 5 & Grad Elective \#1 & Grad Elective \#2 & Grad Elective \#3 & \\
\hline
\end{tabular}

When BS/MS students successfully complete the entire program, they leave RIT with valuable independent research experience, a thesis project completed, and possibly a publication with their name on it. They graduate in the same time as the rest of their entering freshman class, with no additional college loans to pay off in exchange for their advanced degree. Other institutions have active undergraduate research programs, where students participate in semesterlong or year-long research projects individually or as part of a team ${ }^{1,2}$. The general opinion is that the students involved gain valuable experience and learn important new skills, whether or not the project was successful. In RIT's program, however, the student researcher will not receive an MS degree if the thesis work is not completed satisfactorily.

The following sections address the specific challenges that face our BS/MS students and what is being done to overcome these challenges. A discussion of the development of the Graduate Seminar program follows, and results to date are included. Finally, the lessons learned and plans for next year are presented.

\section{Motivation - Current Problems and Goals for Change}

While RIT's BS/MS students are typically the best in their class, and capable of completing the technical thesis requirements, many of them still either fail to complete their thesis in time (within one year of graduation) or do a poor job, which prevent a research program from moving forward because much of the work needs to be re-done by the next student. The Department Head has performed a name-by-name analysis of students not successfully completing a BS degree within 6 years of program entry, but who were on track towards degree completion during year 5. Except for rare cases of extenuating circumstances (such as a major illness), the primary issue for not certifying the BS degree was failure to complete the MS thesis in the dual degree program. In addition to the fact that this means our BS/MS students are not always successful, it means that the overachieving students who are pursuing two degrees simultaneously actually negatively affect our undergraduate retention rate and do not finish in the set amount of time. This issue is unique to RIT's dual-degree program. 
However, there are some common themes that other institutions with undergraduate research experiences report as challenges that are also found at RIT. A report from Kettering University cites loss of student focus, heavy workloads (classes + thesis), and the financial strain of giving up a paid job in favor of unpaid research, among other things ${ }^{1}$. Students and faculty at the Air Force Academy ${ }^{2}$ also cited the classes + thesis workload issue, as well as the students' potential lack of experience or knowledge on the subject to be studied.

Several specific issues have arisen consistently at RIT when asking why BS/MS students are not as successful as they could be. There are similarities to those reported elsewhere, as well as some specific to our dual degree program. These are:

1. There is a shortage of thesis advisors relative to the number of students admitted to the BS/MS program.

2. $5^{\text {th }}$ year students are required to take Senior Design, a two quarter capstone design course; the work level in this course peaks around the same time that thesis writing and defending would occur.

3. Many students must work part-time for financial reasons and have little free time for thesis work.

4. Students are required to co-op between their $4^{\text {th }}$ and $5^{\text {th }}$ years; if they are working on unfunded thesis projects, this means they must spend the summer working full time at a different job and not on their thesis.

5. As an undergraduate institution with few dedicated research labs and little dedicated graduate student space, there is no existing network of graduate students who work together in a particular lab or office.

6. Students do not know what a thesis entails/do not understand the level of thesis work compared with a class project.

7. Students do not know how to start and carry out a literature search.

8. Students must often learn new skills (programming, analysis software, laboratory equipment) that are beyond the scope of their completed coursework, and they do not know what resources are available to them.

The first problem is one that is only solved by reducing the number of BS/MS students or increasing the number of faculty advisors. Both solutions are beyond the students' control, so they are beyond the scope of topics for a Graduate Seminar. Numbers 2-5 are systemic - we cannot change anything about these issues, and the students know they will pose challenges to their dual degree completion, but we may be able to provide ideas on how to work around them. The final three issues, 6-8, are issues that can be changed by providing supplemental instruction or information to our BS/MS students. Because of the lack of a graduate student network, there is no readily apparent opportunity for a beginning BS/MS student to look to an upper-class peer for advice or assistance. As a result, each faculty advisor has had to deal with each of these issues as they come up with each individual student.

The task undertaken for this year has been to develop a series of one-hour seminars to give our $\mathrm{BS} / \mathrm{MS}$ students information about some resources they might not know about as well as suggestions for making their last two years of college/graduate work go more smoothly. The objective is to address points 2-8 above, and begin to develop a community of BS/MS students 
where upperclassmen provide support and some guidance to newer students for the challenges that they are about to face.

\section{Seminar Development}

The first decision was to set the general format of the Graduate Seminar series to be a panel discussion. Many of the issues that our BS/MS students face are similar to the ones we all faced when starting our graduate work. The only difference is the lack of a research team or graduate student peer group from which to learn. By making these seminars panel discussions, the new students grow accustomed to learning from their upper-class peers and not to being lectured to by yet another professor about, "when I was in grad school...". The intent is to have students develop from listeners into panel participants as they gain experience and are able to give advice to new BS/MS students. A conscious effort has been made to avoid lecturing to the students and to make the sessions more interactive, with the end goal being that the students will learn from one another's experiences. Similar approaches were taken at Cornell, with the development of their Teaching Assistant Development Program designed for beginning Teaching Assistants. ${ }^{3}$ The Cornell program has Teaching Fellows, advanced Teaching Assistants, developing and presenting workshops to beginning Teaching Assistants. The RIT program, while designed to develop researchers more than teachers, should follow a similar mentor-based style, rather than a lecture and listen style.

The seminar series is scheduled for one hour per week during the academic year, and it coincides with the time for the College of Engineering Colloquium Series. When there is a colloquium speaker on campus, graduate students have been asked to attend the talk to get broader exposure to engineering issues beyond classes in their own major or research area. This accounts for approximately 15 weeks spread out over the course of our 30-week academic year. During the remaining meetings, students will come listen to a speaker or a panel of senior BS/MS students discuss the topic of the week. For the first year, the topics will be new to all of our BS/MS students, so some difficulty in finding experienced panelists was anticipated.

Lilja $^{4}$ has compiled suggestions for teaching students the research process. Since that is partly the aim of the seminar series described here, several of his ideas were incorporated. Those were to (1) help students critically evaluate others' work, (2) provide opportunities to do real research, (3) encourage focused activity on the research topic, and (4) teach them the fundamental (measurement) tools in the field. Those have been interpreted here as follows: (1) learn how to approach a literature search - finding papers and deciding which ones are relevant, (2) actively taking the lead on an independent thesis project, (3) learning to recognize when your work is futile or unproductive and when you need to redirect your efforts, and (4) learn the technical (software, hardware) and nontechnical (communications, time management) skills required to do engineering research.

Lessons learned from the Cornell program ${ }^{3}$ also apply to the seminar series being developed here. Some of the feedback reported by Roberts, et al. that was incorporated at RIT includes ${ }^{3}$ : students want advice from peers, rather than out-of-touch administrators; let students evaluate the sessions immediately instead of at the end of the session; lecture format doesn't work, so eliminate it; give us the information we need in time, not too late; we want workshops on dealing 
with problems that TA's face; and include personal experiences and how they were handled. Correspondingly, the RIT program can address many of these by using the student panel approach, where $5^{\text {th }}$ year students share their experiences and insights with $3^{\text {rd }}$ and $4^{\text {th }}$ year students - the approach avoids the lecture format and provides peer advice/solutions to the audience. A brief feedback form has been developed to get immediate student feedback on each session, and the timing of topics has also been considered.

Table 2: One-year Graduate Seminar schedule. The final column indicates events occurring during the academic year that relate to the seminar topics.

\begin{tabular}{|c|c|c|}
\hline \multicolumn{2}{|r|}{ Topic } & Related Event \\
\hline \multicolumn{3}{|c|}{ Fall } \\
\hline 1 & $\begin{array}{l}\text { Starting Your Literature Search } \\
\text { Speaker: RIT Library Engineering Collections } \\
\text { Librarian }\end{array}$ & $\begin{array}{l}\text { Many students start thesis } \\
\text { work in early fall of } 4^{\text {th }} \text { year }\end{array}$ \\
\hline 2 & $\begin{array}{l}\text { Defining Thesis Goals and Milestones } \\
\text { Speaker: Student panel }\end{array}$ & $\begin{array}{l}\text { Thesis proposals are due, } \\
\text { students need a plan of work }\end{array}$ \\
\hline 3 & $\begin{array}{l}\text { Effective Communication } \\
\text { Speaker: Presentation by faculty }\end{array}$ & \\
\hline \multicolumn{3}{|c|}{ Winter } \\
\hline 1 & $\begin{array}{l}\text { Making the Most of Meetings w/Your Advisor } \\
\text { Speaker: Faculty panel }\end{array}$ & \\
\hline 2 & $\begin{array}{l}\text { How to Find a Thesis Topic on Your Co-op } \\
\text { Speaker: Student panel }\end{array}$ & $\begin{array}{l}\text { Students begin applying for } \\
\text { summer co-ops now }\end{array}$ \\
\hline 3 & $\begin{array}{l}\text { Dealing with Thesis Roadblocks } \\
\text { Speaker: Student panel }\end{array}$ & \\
\hline 4 & $\begin{array}{l}\text { Fellowship Opportunities to Fund Grad Study } \\
\text { Speaker: Department Head }\end{array}$ & $\begin{array}{l}\text { Many scholarship applications } \\
\text { are due in the spring }\end{array}$ \\
\hline 5 & $\begin{array}{l}\text { Technical Writing } \\
\text { Speaker: Faculty from Communications Dept. }\end{array}$ & \\
\hline \multicolumn{3}{|c|}{ Spring } \\
\hline 1 & $\begin{array}{l}\text { Welcome to New BS/MS Students } \\
\text { Speaker: Faculty/Student panel }\end{array}$ & $\begin{array}{l}\text { New BS/MS students are } \\
\text { accepted late in Winter quarter }\end{array}$ \\
\hline 2 & $\begin{array}{l}\text { Writing a Good Literature Search } \\
\text { Speaker: Student panel }\end{array}$ & $\begin{array}{l}\text { Students have now had some } \\
\text { time to start literature search }\end{array}$ \\
\hline 3 & $\begin{array}{l}\text { Research Ethics Case Study } \\
\text { Speaker: Department Head }\end{array}$ & \\
\hline 4 & $\begin{array}{l}\text { Combining Thesis and Senior Design } \\
\text { Speaker: Student panel }\end{array}$ & $\begin{array}{l}\text { Students may be able to } \\
\text { develop a Senior Design } \\
\text { project for next fall to support } \\
\text { their thesis work }\end{array}$ \\
\hline 5 & Balancing Thesis and Co-op & $\begin{array}{l}\text { Students whose co-op is not } \\
\text { thesis-related are about to } \\
\text { leave for the summer }\end{array}$ \\
\hline
\end{tabular}


Seminar topics have been scheduled to coincide with other events going on during the academic year. For example, during late winter and early spring, many scholarship applications are due, and this is when students begin applying for summer co-op positions. Therefore, seminars relating to graduate fellowship opportunities and topics relating to co-op work and thesis were scheduled for January and February. Students are accepted into the BS/MS program during March, so an early spring seminar would be a welcome and orientation session for new students. Students typically are encouraged to begin work on their thesis at the start of their $4^{\text {th }}$ year, so topics that will help students come up to speed were scheduled for fall and early winter. The first year schedule is given in Table 2, along with the academic year events the seminar is designed to support. In addition, a mid-year mailing was sent out with a list of research projects for which faculty were seeking assistance.

For evaluation purposes, each student attending a Seminar was asked to fill out a response form. Students were asked to rate the meeting on a scale of 1 (not helpful) to 5 (very helpful). They were also asked what the most useful piece of information they learned was and what they would like to see included in the meeting during the next offering.

Results and Observations

Several supplemental resources have been supplied for our BS/MS students. Many resources have been assembled online under the course webpage so any BS/MS student can access them from any location. Some resources have been assembled as handouts for students attending the seminars. Please refer to Appendix 1 for samples of some of the resources provided.

- Literature Search Resources: Contact information for the Engineering Reference Librarian, who has volunteered to help students start their literature searches. Links to search engines such as Web of Science, ArticleFirst, and our own library search pages.

- Thesis Milestones Resources: A presentation given during the seminar on time management tips. Information on the students who sat on the discussion panel. The students gave a brief overview of how they used a planning tool (Microsoft Project) to help set up a timeline.

- Effective Meetings with Your Advisor: A weekly worksheet to bring to meetings with their thesis advisor. This includes a chart to track how much time was spent, and what was accomplished, in order to determine if the student is working effectively or as often as he/she thinks; a running to-do list; a list of previous week's accomplishments and next week's goals; a list of information or help needed from the advisor. These lists will help students understand how well they are budgeting their time and they will help the advisors keep track of each different student's progress.

- Technical Writing: Links to some online guides to technical writing, including links at other universities and author guidelines from major engineering organizations. Our students get no formal training in technical writing.

- Fellowship Opportunities: Contact information for organizations that provide funding for graduate work. If students are required to stay beyond completion of their BS coursework, they may be eligible for graduate fellowships. Many students currently leave RIT to start full-time jobs, where "I will work on my thesis during evenings and weekends".

- Fluent Working Session: Since we have no real graduate student community, a working session for learning Fluent, the computational fluid dynamics (CFD) software used at RIT, was organized for a group of BS/MS students who needed to use it for their thesis. These 
students were working independently, unaware that there were others trying to figure out the same problems. By getting them together to work, we hope to have accelerated the learning process and demonstrated to these students that they are not alone and that there are others who can help.

As of the paper submission date, the first four Graduate Seminar sessions have met. Since a large number of students were on co-op, some had course conflicts, and many students had no thesis topic on which to work, attendance has been limited so far. Table 3 displays the results of the student feedback surveys. Of the students that do attend the seminar regularly, most seem to feel that the sessions are helpful. One of the most interesting observations from the feedback forms was that our students did not know at all what to expect of a thesis project. They did not realize that it would be "their" project - the advisor would be there for guidance, but the student should be more in control of what work will be done. They had no idea what library resources were available besides the reference books and Google searches online.

Table 3: Results of student feedback surveys. A rating of 5 is "very helpful" and a rating of 1 is "not at all helpful".

\begin{tabular}{|c|c|c|}
\hline Session & Average (\#returned) & General Comments \\
\hline Starting a literature search & 3.75 (4 surveys) & $\begin{array}{l}\text { Most students did not realize how many } \\
\text { resources were available. }\end{array}$ \\
\hline Defining thesis goals & 4.2 (5 surveys) & $\begin{array}{l}\text { Students were interested in learning } \\
\text { Microsoft Project, but would like some } \\
\text { guidance from the advisor when setting } \\
\text { up a timeline. }\end{array}$ \\
\hline Effective communication & 3.75 (6 surveys) & $\begin{array}{l}\text { Students were interested in the sample } \\
\text { presentation, which included some } \\
\text { good slides and some bad slides to } \\
\text { contrast. Some asked for a chance to } \\
\text { do their own presentation next time. }\end{array}$ \\
\hline Effective advisor meetings & 4.2 (5 surveys) & $\begin{array}{l}\text { Students appreciated the meeting } \\
\text { worksheet handout, and were glad to } \\
\text { learn that they would generally be } \\
\text { expected to run the meetings - that } \\
\text { their advisors would be guiding not } \\
\text { controlling. }\end{array}$ \\
\hline $\begin{array}{l}\text { Finding a thesis project on } \\
\text { your co-op }\end{array}$ & $\begin{array}{c}\mathrm{n} / \mathrm{a}(6 \text { students } \\
\text { attended, no surveys } \\
\text { returned) }\end{array}$ & $\begin{array}{l}\text { This was the most animated discussion } \\
\text { of all the topics - three students told } \\
\text { their thesis project development stories } \\
\text { and the audience members asked } \\
\text { questions until time ran out. Many } \\
\text { were interested in funding issues. }\end{array}$ \\
\hline Dealing with thesis roadblocks & 4.0 (8 surveys) & $\begin{array}{l}\text { Students wanted an interactive session } \\
\text { where they could share problems and } \\
\text { solutions. There were four suggestions } \\
\text { to deal with the roadblock of finding a } \\
\text { topic in the first place. }\end{array}$ \\
\hline
\end{tabular}


The concept of student panels has been successful so far. The Seminar coordinator was able to find two or three students to sit as panelists for each topic that required a panel. Students who served as panelists seemed to enjoy being able to share their experiences with others, and viewed it as an honor rather than an extra time commitment. The hope is that next year, more students will have experience in these areas and will be able to serve as panelists.

The most important observation made this year was that there are many more BS/MS students than there are available thesis topics and advisors. The relatively low attendance at the Graduate Seminar meetings was partly because, while the topics were geared toward helping students get started on their thesis work, most of our students do not even have thesis topics yet. As a primarily undergraduate institution, many faculty are not actively pursuing research projects: 6 out of 23 tenured, tenure track, or research-based faculty have no BS/MS students; another 6 faculty only work with one. This leaves 11 faculty to support approximately 55 BS/MS students. Many people are aware that this problem exists, but had not realized the extent. The issue is beyond the scope of the activities related to this seminar development, but without the seminar series, the issue might not have been brought so clearly to the forefront.

Finally, it is clear that attendance at these sessions was low, despite the attendees' favorable reviews. This is primarily due to two factors: first, during any given quarter approximately half of our upperclassmen are away on co-op, and second, our BS/MS students tend to have very full schedules and there were many class conflicts with the session time. As a 0-credit course, the Graduate Seminar was not a priority in many students' planning. A course web page has been developed, and three students have actually emailed the coordinator from their co-op locations asking to get the information disseminated during the seminars.

Conclusions and Future Plans

So far, the Graduate Seminar series has been helpful in beginning to expose dual BS/MS students to the new challenges and responsibilities that come along with doing independent research. While attendance has been low, it has brought to the forefront a significant challenge in our program - to provide enough thesis projects and advisors for our students. Steps are being taken toward this end with the introduction of a BS/MEng program that does not require a thesis. In the future, all students will be accepted into the BS/MEng program and they will only be able to transfer to the MS option once they have secured an advisor and thesis topic, and have begun a literature search. Once students realize the amount of independent, self-defined work that is required for a thesis, many will likely opt for the MEng track on their own. Several previously $\mathrm{BS} / \mathrm{MS}$ students have already requested a switch into the BS/MEng track, which is now home to 26 dual degree students. By using this seminar series to educate students on the more intangible requirements of the MS, potential students can be guided toward the best choice for their interests.

Since a common response on the feedback forms was a desire to try more things themselves, next year's Graduate Seminar will include a Technical Writing session where students swap thesis proposals and peer edit, as well as quarterly opportunities for students to do brief (10-15 minute) presentations on their own thesis progress to get peer feedback. More student working 
groups will be developed: for CFD analysis, finite element analysis, and using particular pieces of test equipment. This will help the students realize that they are a community, not isolated researchers working completely on their own.

For the more informative, less active topics, we anticipate that next year's $5^{\text {th }}$ year students, who have been through the thesis-starting process once, will be eager to share their experiences with $3^{\text {rd }}$ and $4^{\text {th }}$ year BS/MS students who are just getting started.

As RIT makes more of an effort to involve undergraduate students in research, the Graduate Seminar Series will play an important role in the maturity of these students into effective graduate students and researchers. RIT will benefit by capitalizing on the research abilities of this student group, and our undergraduates will have the opportunity to develop in areas that compliment their technical skills.

\section{References}

[1] Erevelles, Winston, "Experiences in Integrative Research and Education Projects with Undergraduate Engineers", Proceedings of the American Society for Engineering Education Annual Conference and Exposition, Charlotte, NC, 1999.

[2] Formwalt, Bryon; Hayes, Matthew; Pittner, David; and Pack, Daniel, "Undergraduate Research: How can it be made effective?" Proceedings of the American Society for Engineering Education Annual Conference and Exposition, Milwaukee, WI, 1997.

[3] Roberts, Susan C., Hollar, Kathryn A., and Carlson, Virleen M., "Looking Back: Lessons Learned from Ten Years of Training Teaching Assistants", Proceedings of the American Society for Engineering Education Annual Conference and Exposition, Milwaukee, WI, 1997.

[4] Lilja, David L., "Suggestions for Teaching the Engineering Research Process", Proceedings of the American Society for Engineering Education Annual Conference and Exposition, Milwaukee, WI 1997.

\section{Biographical Information}

ELIZABETH A. DeBARTOLO is an Assistant Professor in the Mechanical Engineering Department at the Rochester Institute of Technology. She earned her BSE at Duke University in 1994 and her Ph.D. at Purdue University in 2000. She works with several dual BS/MS degree students on predicting and enhancing fatigue life in aircraft materials and structures.

EDWARD HENSEL, registered professional engineer, is Professor and Head of the Mechanical Engineering Department and Professor of Microsystems Engineering at the Rochester Institute of Technology. He earned his BS in mechanical engineering from Clarkson, and his $\mathrm{PhD}$ from New Mexico State University. 
Appendix: Sample Information Available to BS/MS Students - Handouts and Online Resources

Figure 1: Sample weekly report template used by Dr. Risa Robinson, an RIT ME faculty member, in meetings with her BS/MS students.

Name:

Week (Mon-Sun):

Weekly Report

\begin{tabular}{|l|l|l|l|l|}
\hline Day & Time In & Time Out & Total Hours & $\begin{array}{c}\text { Major } \\
\text { Accomplishments }\end{array}$ \\
\hline & & & & \\
\hline & & & & \\
\hline & & & & \\
\hline & & & & \\
\hline & & Total & & \\
\hline
\end{tabular}

Accomplishments this week:

Goals for next week:

Running to do List:

Help needed from thesis advisor: 
Figure 2: Course web page with resources for students just beginning their literature search. The engineering librarian spoke and offered to provide students one-on-one help getting started. The three student panelists were all recommended by their advisors as students who had done good literature searches of their own.

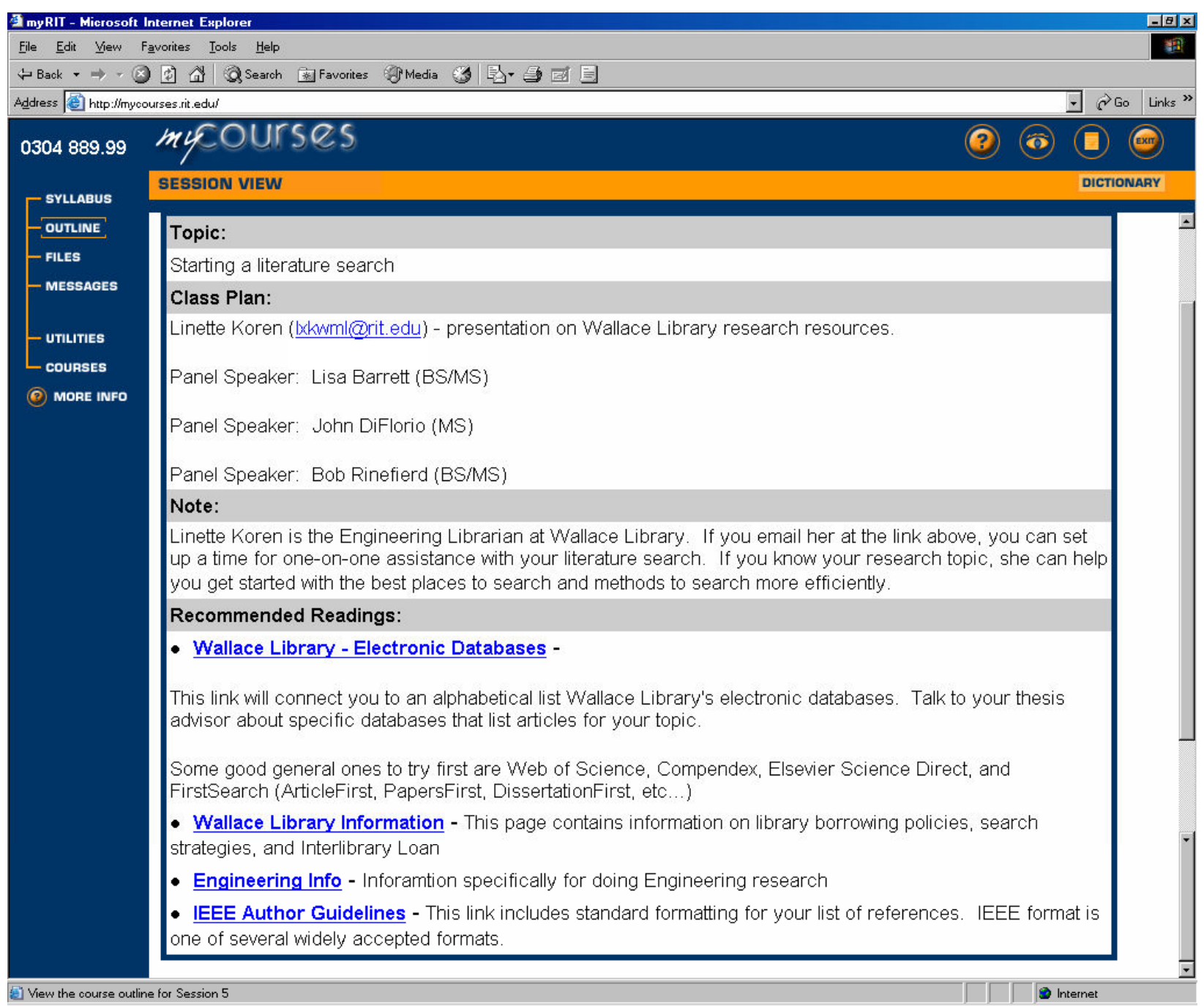


Figure 3: Course web page including links to potential funding sources and a copy of the department head's presentation on paid research/teaching opportunities in the ME department.

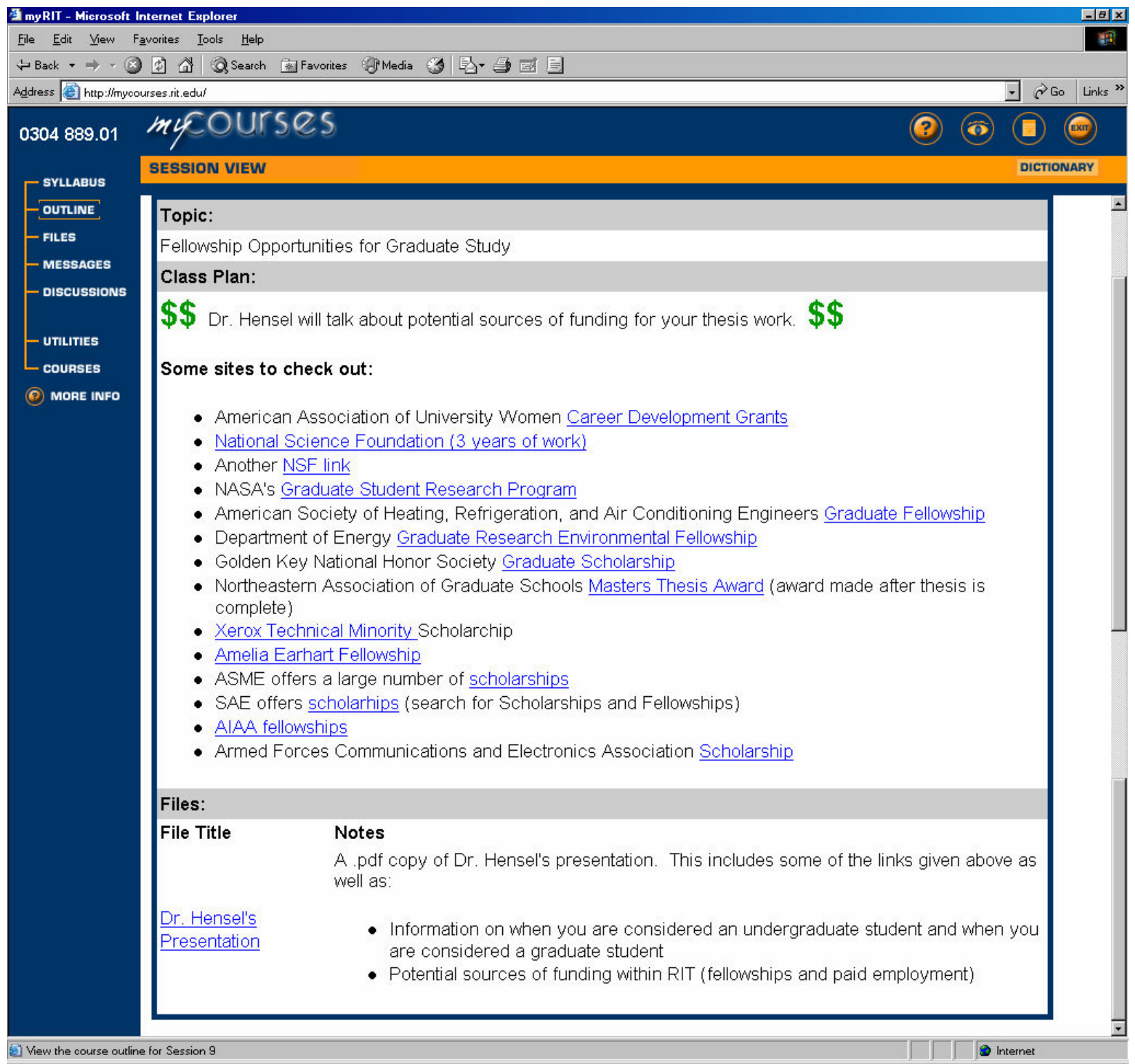


Figure 4: Course web page from the discussion on finding a thesis project while on co-op. Suggestions from panelists were compiled to post online at the request of several students who were on co-op and could not attend the meeting.

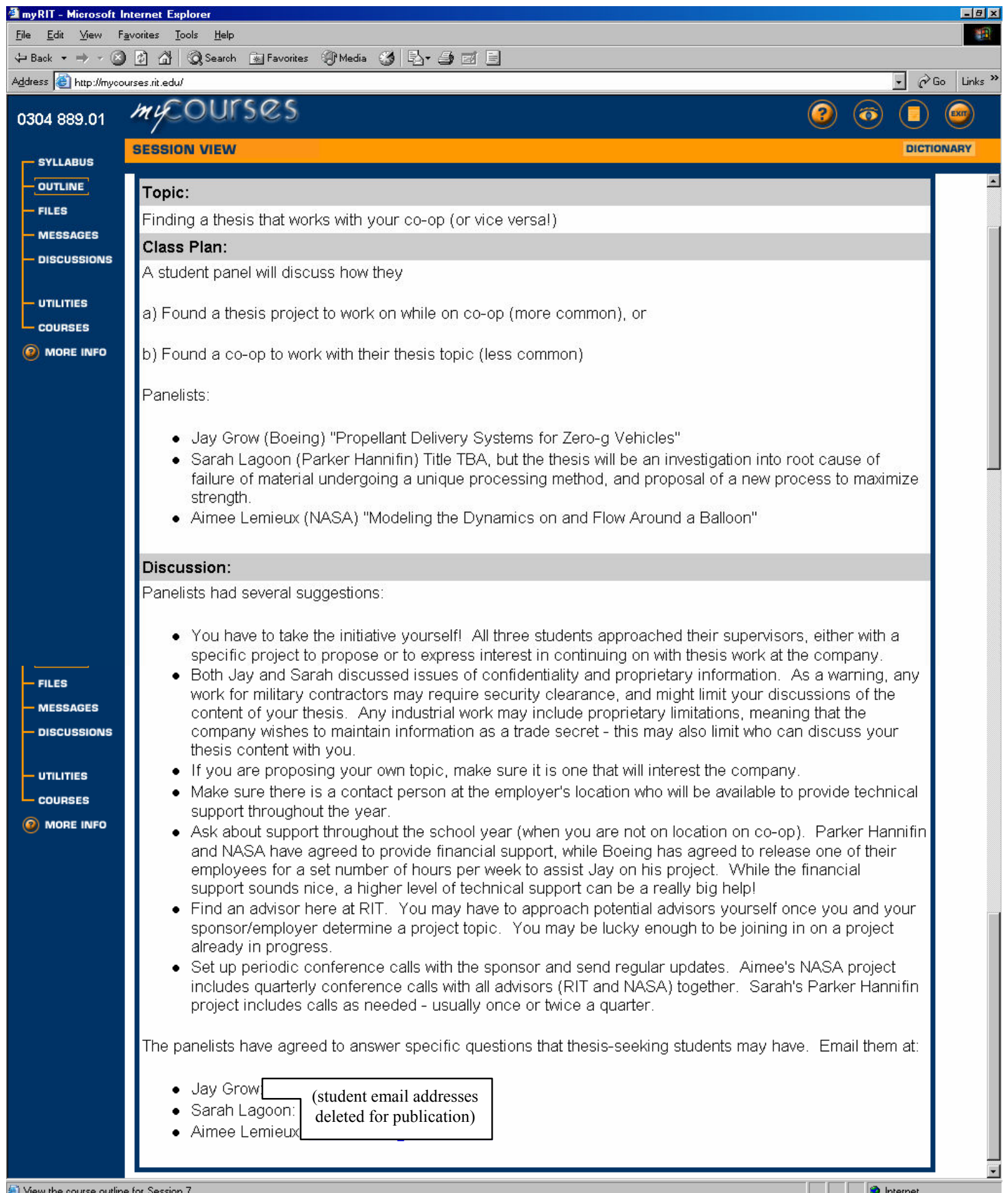

